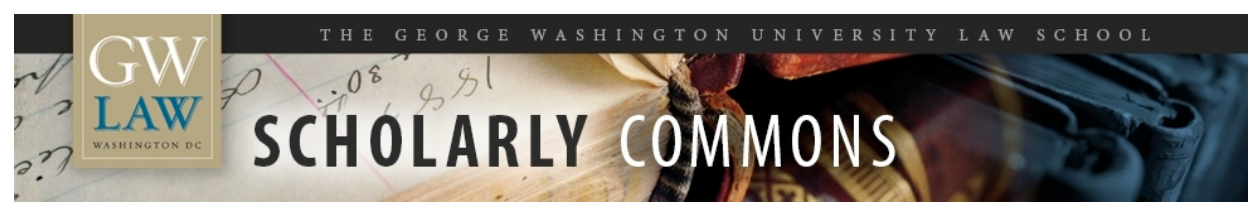

\title{
Addressing Government Failure Through International Financial Law
}

Steve Charnovitz

George Washington University Law School, scharnovitz@law.gwu.edu

Follow this and additional works at: https://scholarship.law.gwu.edu/faculty_publications

Part of the Law Commons

\section{Recommended Citation}

Steve Charnovitz, "Addressing Government Failure Through International Financial Law," 13 J. Int'I. Econ. L. 743 (2010).

This Article is brought to you for free and open access by the Faculty Scholarship at Scholarly Commons. It has been accepted for inclusion in GW Law Faculty Publications \& Other Works by an authorized administrator of Scholarly Commons. For more information, please contact spagel@law.gwu.edu. 


\title{
ADDRESSING GOVERNMENT FAILURE THROUGH INTERNATIONAL FINANCIAL LAW
}

\author{
Steve Charnovitz ${ }^{\star}$
}

\section{ABSTRACT}

This study examines the causes of the financial crisis and proposes better policies at the international level. Based on a framework that sees government failure as a significant source of the problem, the study examines the new US Dodd-Frank legislation and critiques the Congressional approach to avoiding systemic risk. The study also presents a survey of the organizational efforts aimed at international financial reform and coordination, and critiques the lack of openness and public dialogue at the recent G-20 Summit in Toronto. Finally, the study proposes importing some techniques used in the World Trade Organization (WTO) and the International Labour Organization (ILO) to monitor national policies.

In the course of years-in the course of a century--economic lines, drawn ever tighter, have been tied among the peoples. National economies have become more and more independent. Beside and above them, or, to put it better, among them, a world economy has been formed. And the common problem in which are united these various problems may be stated in these terms: give to world economy its fundamental law (ILO, 1923). ${ }^{1}$

\section{INTRODUCTION}

As the International Labour Organization (ILO) observed in 1923, a world economy needs appropriate law. Recognition of the importance of economic law harks back to antiquity, ${ }^{2}$ and yet each era strives to establish and nurture the optimal norms and institutions required for contemporary and anticipated future problems. As the visionary economist Eugene Staley once explained: "Economic problems can never be "solved" once and for all.

* Associate Professor of Law, The George Washington University Law School. E-mail: scharnovicz@law.gwu.edu

1 Wallace McClure, World Prosperity as Sought Through the Economic Wbrk of the League of Nations (New York: The Macmillan Company, 1933), 279, note 38, translating ILO, Enquête sur la Production, Rapport général, Tome V, Deuxième volume (Geneva: ILO, 1923) 1592.

2 See generally Benn Steil and Manuel Hinds, Money, Markets and Sovereignty (New Haven: Yale University Press, 2009) ch 2. 
The very essence of economic problems is change, readjustment to new conditions. ${ }^{3}$

The world financial crisis of 2007-201? has revived the attention of policymakers and citizenry as to the need for more effective public and private governance of financial markets. In 2009 , world output fell by $0.6 \%$ and world trade fell by $10.7 \% .^{4}$ Since the financial crisis began, the number of unemployed people in the world has risen by about 34 million. ${ }^{5}$

The governmental response to the financial crisis has occurred at all levels, from the local to the global. In considering how to improve such policy responses, analysts should proceed from a perspective that distinguishes the national from the international and market failures from government failures. Below is a brief overview of the relevant policy matrix.

At the national level, governments respond to market failure, such as pollution, using instruments of regulation, tax, and subsidy. These interventions are complemented by private standard-setting mechanisms that improve information and seek efficiencies. As yet, no one has invented a cure for the business cycle, and governments use fiscal and monetary policy to boost weak economies.

The problems of government failure are more inchoate. Inefficient and counterproductive regulation, subsidies to politically favoured special interests, and wasteful government spending are corrected on an ad hoc basis through elections, so-called reform legislation, and public law litigation. To some extent, the market can also be a corrective as jurisdictions compete for investment and governmental reputation.

At the international level, the problems of market and government failure become more acute, and as John H. Jackson has noted, 'the kinds of government responses possible at the nation-state level differ dramatically from those at the international level'. 6 The world 'ecolonomy' encompasses all of the problems within each country, but then is also challenged by conflicting sovereign regulation of transborder problems and by governmental policies that seek to externalize costs onto other countries. The classic examples of the latter are beggar-thy-neighbour trade policies, currency depreciation, and expropriation of foreign assets. The provision of global public goods, such as public health, is also a major challenge in -governance beyond the nation-state.

Governance of transborder market failure has historically been weak, but has been strengthened in recent decades by the Organisation for Economic

${ }^{3}$ Eugene Staley, World Economy in Transition (New York: Council on Foreign Relations, 1939) 300.

4 International Monetary Fund, 'World Economic Outlook', April 2010, 155, 170.

5 ILO, 'Global Employment Trends', January 2010, 47.

- John H. Jackson, Sovereignty, the WTO, and Changing Fundamentals of International Law (Cambridge: Cambridge University Press, 2006) 221. 
Co-operation and Development (OECD), the International Competition Network, the Basel Committee on Banking Supervision, the International Organization of Securities Commissions, and the Financial Stability Board. In contrast to the thick international lawmaking for dealing with the effects of market failure on the environment, there is little hard law in the financial arena. ${ }^{7}$ As Thomas Cottier has noted: 'It seems paradoxical that financial services are among the most regulated businesses in domestic law, but that no rules of such significance exist on the global level for the most advanced global players'.

The market failure of inadequate capital for investment (particularly public investment and adequate liquidity) is addressed through the regular lending programmes of the International Monetary Fund (IMF) and the World Bank. When a sovereign debt crisis occurs, which has happened recently in Greece, the international lending that ensues is more precisely termed a response to government failure than to market failure. A classic government failure occurs when a government overspends to propitiate special interests, runs up high deficits, and mismanages the domestic economy so badly that the only way for the government to dig itself out of debt is via induced inflation, currency depreciation, and financial default.

The oversight of transborder government failure exists in some areas but not others. The earliest international law of that sort was the ILO Constitution, enacted in 1919, which is premised on the view that 'the failure of any nation to adopt humanc conditions of labour is an obstacle in the way of other nations which desire to improve the conditions in their own countries'.9 The IMF, established in 1944, has as one of its purposes 'to promote exchange stability, to maintain orderly exchange arrangements among members, and to avoid competitive exchange depreciation'. ${ }^{10}$ The IMF influences governments through rules and through conditional loan agreements. ${ }^{11}$ Much more so than the World Trade Organization (WTO), the IMF has a strong burcaucrat-driven economic surveillance capacity. Recently, the IMF has sought more harmonization of financial regulation. ${ }^{12}$

The WTO and the preceding General Agreement on Tariffs and Trade (GATT) have been successful in managing the transborder government failure of protectionism. For public choice reasons, governments are prone to protecting a domestic economy from foreign competition either directly through tariffs or quotas or indirectly through nontariff barriers and

${ }^{7}$ See Brummer, in this issue at 623-643.

8 Thomas Cottier, 'Challenges Ahead in International Economic Law', 12 Journal of International Economic Low 3 (2009), at 7-8.

9 Constitution of the ILO, Preamble.

10 IMF Articles of Agreement, Article 1.

11 Sec Baltensberger and Cottier, in this issue at 911-937.

12 Marcus Walker and Stephen Fidler, 'IMF Chief Urges Coordinated Finance Rules', W'all Street fournal, 30-31 January 2010, A11. 
subsidies. WTO law hardly eliminates these practices, but it does make governmental measures more transparent and outlaws (or limits) the most egregious practices, such as export subsidies.

The international economic order does not contain an institution, analogous to the ILO, the IMF, or the WrO, to supervise and prevent government failures that lead to transborder financial problems. This lacuna has been filled over the past 11 years by the G-20, which has had some success in addressing market failure but less in addressing government failure. The role of the G-20 continues to be amorphous. WTO Director-General Pascal Lamy has explained that the G-20 is 'an embryo of consensus building' but that the G-20 itself 'does not decide', leaving the making of 'internationally binding decisions' to member-driven international agencies. ${ }^{13}$ Given the state of play, the purpose of this article is to propose improvements in international economic law and its institutions so as to prevent a repeat financial crisis in the USA and around the world.

The remainder of the article has four parts: Part II examines the causes of the recent crisis. Part III proposes substantive policy changes to enhance recovery. Part IV examines the role and techniques of international institutions. Part V concludes.

\section{CAUSES OF THE CRISIS}

The conventional narrative is that the US financial crisis was caused by excessive and risky speculation on Wall Street, greedy bankers, industry capture of the regulation on derivatives and swaps, and abuses in the mortgage markets whereby banks took advantage of innocent homeowners. Although all of that may have occurred to some extent, that narrative is incomplete at best because it suggests that the cause of the crisis originated in an unregulated market. That view is naive because it confuses symptoms with causes and misses the role of government in causing and exacerbating the crisis. In my view, the financial meltdown was at least as much a product of government failure as it was of market failure. ${ }^{14}$ One of the core government failures was the breakdown in the long-time regulatory and supervisory distinctions between investment and depositary banking. ${ }^{15}$

"Speech of Director-General Lamy, 'The Global Trading System and the World Economy', Seoul, 7 December 2009, http://www,wto.org/english/news_e/sppl_e/sppl144_e.htm (visited 12 September 2010).

${ }^{14}$ See Allan H. Meltzer, 'Market Failure or Government Failure?', Wall Street fournal, 19 March 2010, A19.

15 Cynthia Crawford Lichtenstein, 'Lessons for the $21^{\text {" }}$ Century Central Bankers: Differences between Investment and Depositary Banking', in Mario Giovanoli and Diego Devos (eds), International Monetary and Financial Law: The Global Crisis (Oxford: Oxford University Press, 2010) 217-33. 
The US crisis started with large asset bubbles fed by lax monetary policy ${ }^{16}$ and ill-advised government subsidies in the housing sector. The proximate cause of the crisis may have been the declining value of mortgage bonds and collateralized debt obligations (the misnamed 'toxic assets'), but the real cause was the government policy of buying mortgages through the off-budget entities Fannie Mae and Freddie Mac and hence guaranteeing payment. No wise government would guarantee that home investors would repay a mortgage without some method of collecting from derelict homeowners. ${ }^{17}$ Nonetheless, the US government did so, and compounded the error by making it easier for home investors to walk away. without any tax consequences and by discouraging banks from foreclosing in a timely fashion. For years, risk watchers had pointed out the dangers as Fannie and Freddie grew bigger, but US politicians refused to take serious measures to rationalize housing lending. ${ }^{18}$ Indeed, Senate Banking Committee ${ }^{19}$ Chairman, Christopher Dodd, took part in a preferential deal on mortgage refinancing from Countrywide, one of the banks that collapsed during the crisis. $^{20}$ Even worse, Congressman Barney Frank famously opined that he wanted to 'roll the dice a little bit more' in the interest of expanding federal subsidies for homeowners. ${ }^{21}$ Ironically, such subsidies do not help and may even hurt the $33 \%$ of American families who are not homeowners, often because they cannot afford to be. The federal government bailout of Fannie and Freddie has now cost the federal government over $\$ 145$ billion in direct aid, and many tens of billions more have been given in direct and indirect aid to homeowners whose mortgages are under water. Unfortunately, the ironically named Dodd-Frank Wall Street Reform and Consumer Protection Act of $2010^{22}$ contains no reforms of the mess at Fannie and Freddie. ${ }^{23}$

The 'too big to fail' commitment to large investment banks and insurance companies by the Federal Reserve and the US Treasury led to massive loans which undermined confidence in the US economy. Although Warren Buffett's loan to Goldman Sachs in September 2008 provided a template for how the US government could make a smart loan to a bank that needed liquidity, the US Treasury acted to demand that large banks take 'cheap

${ }^{16}$ See Hufbauer and Xie, in this issue at 939-953.

17 See Nick Timiraos, 'Why Hasn't Canada's Housing Market Blown Up?', Woll Street Journal, 7 December 2009.

${ }^{18}$ Robert G. Wilmers, 'What About Fan and Fred Reform?', Wall Street Journal, 4 May 2010.

${ }^{19}$ US Senate Committee on Banking, Housing, and Urban Affairs.

20 'Dodd and Countrywide', Wall Strect Journal, 10 October 2008, http://online.wsj.com/article' SB122360116724221681.html (visited 26 June 2010).

21 'What They Said Abour Fred and Fan', W'all Street Journal, 2 Ocrober 2008, http:/online.wsj .com/article/SB122290574391296381.hunl (visited 26 June 2010).

${ }^{22}$ H.R. 4173, Public L. 111-203, http://financialservices.house.gov/Key_Issues/Financial_ Regulatory_Reform/Final_conference_titles/T1_FINAL.pdf (visited 26 June 2010).

${ }^{23}$ John B. Taylor, 'The Dodd-Frank Financial Fiasco', W'all Street Journal, 1 July 2010, Al9. 
capital' government loans even when they did not request it, ${ }^{24}$ and then later by using the loans to justify heavy-handed regulation of investment strategies and vilification of Wall Street investment and compensation practices. ${ }^{25}$ In my view, allowing the investment bank Bear Stearns to fail would have sent the right signal to Wall Street. The same is true for AIG, which received credit infusions of about $\$ 182$ billion from the Treasury and the Federal Reserve.

After the Congressional conference committee completed negotiations on the Dodd-Frank bill in June 2010, President Barack Obama extolled the then-pending legislation saying: 'The reforms making their way through Congress will hold Wall Street accountable so we can help prevent another financial crisis like the one that we're still recovering from' ${ }^{26}$ Yet it is hard to see how this legislation, had it been in effect four years ago, would have made much difference. The central regulatory thrust of Dodd-Frank is to establish a Financial Stability Oversight Council (Council) composed of 10 voting members, nine from the federal government and one independent expert with insurance expertise. The Council also has five non-voting members including two federal officials and three state government officials. The statutory purpose of the Council is to identify risks to the financial stability of the United States that could arise from the material distress or failure ... of large, interconnected bank holding companies. $, 2,27$ to respond to such emerging threats with regulation, and 'to promote market discipline, by eliminating expectations on the part of shareholders, creditors, and counterparties of such companies that the Government will shicld them for losses in the event of failure'. ${ }^{28}$ The Council is exempt from the normal transparency requirements in the Federal Advisory Committee Act. ${ }^{29}$

Identifying unanticipated risk is hard and there is no reason to think that the same busy federal officials, who apparently overlooked these risks in 2006 and 2007, will become more prescient simply because they serve together on an elite Council. The presence of the one independent expert is helpful, but there was no lack of experts in the late 2000s who warned of an impending financial collapse. There were also some savvy investors and economists who anticipated the collapse, ${ }^{30}$ but the financial regulators and the US intelligence community apparently took no notice of that.

${ }^{24}$ Henry M. Paulson, Jr., On the Brink: Inside the Race to Stop the Collapse of the Global Financial System (New York: Business Plus, 2010) 364-66.

25 James R Hagerty and Ruth Simon, 'For Financial Engineers, A New Risk: Washington', Wal Street Journal, 2 February 2010, C1; Michael R. Crittenden, "Treasury Makes Banks Pay a TARP Premium", Wal Street Journal, 20 January 2010, C3.

${ }^{26}$ Remarks by the President on Wall Street Reform, 25 June 2010, http://www.whitehouse .gov/the-press-office/remarks-president-wall-street-reform-1 (visited 26 June 2010).

27 Title I, Section $112(A)$ of the Dodd-Frank Act.

28 Title I, Section 112(B) of the Dodd-Frank Act.

29. 5 U.S.C. Appendix, Public L. 92-463, Aproved 6 October 1972 (86 Stat. 770).

${ }^{30} \mathrm{See}$ Lastra and Wood, in this issue at 531-550. 
The inescapable conclusion is that a Council dominated by government bureaucrats is unlikely to be able to predict and manage systemic risk. This is particularly so when the mandate of the Council does not include oversight of the government-induced sources of risky behaviour such as huge, uncontrolled budget deficits, lax monetary policy, and corrupt relationships between federal legislators and banks. ${ }^{31}$ The omission from the Council of foreign regulators, academic economists, and consumer watchdog groups and other independent voices suggests that risk regulation in the US government will not be fundamentally different after the new law than it was before. Indeed, the chair of the new Council is the Secretary of the Treasury who presumably already has a full-time job.

The new US model of risk management by wise guardians is misguided. The best way to avoid risks to US financial stability is to use markets to identify the risk and put prices and values on it. Indeed, that was the beauty of the over-vilified and now-to-be heavily regulated credit default swaps because they showed in hard numbers how the market was valuing distressed debt. The same is true of short selling which helps to purify prices in an uncertain market. The notion embedded in the legislation that this new Council can 'promote market discipline' is risible because, in fact, only markets can establish market discipline. ${ }^{32}$ If there was an expectation by shareholders, creditors, and counterparties that the federal government would bail them out, that expectation was justified because many of them did get bailed out, as did the debtors. Those bailouts were wrong, but future expectations will not be changed by government officials giving minatory speeches.

It was not expectations that caused the bailouts; the bailouts were caused by the government officials who chose to gratify those expectations. The way to avoid future bailouts is to repeal government power to use tax dollars or borrowing to provide more bailouts. Moreover, the time has come to end the federal subsidy programmes that have created an entitlement mentality among the American people. ${ }^{33}$ For example, the Dodd-Frank Act provides a retroactive increase in bank deposit insurance to socialize the losses for individuals with large sums of money in banks that failed.

The low point of the financial crisis came in mid-September 2008 when financial markets appeared 'frozen' and close observers thought that 'the

${ }^{31}$ Earle B. Hammond Jr., 'Risk? Let Congress Look in a Mirror', Wall Street gournal, 9 December 2009, A26.

${ }^{32}$ See Robert E. Litan, 'Econumics: Global Finance', in P.J. Simmons and Chantal de Jonge Oudraat (eds), Managing Global Issues: Lessons Learmed (Washington: Carnegie Endowment, 2001) 196-233 at 226 ("Hence one challenge that should be uppermost in the minds of financial policy makers is to find ways of harnessing the forces of the market to help ensure the stability of the financial system....I helieve that a superior approach to incorporating the views of the market into capital standards would rely explicitly on the judgments of the market itself').

${ }^{33}$ See Peter G. Peterson, Running on Empty (New York: Farrar, Straus, and Giroux, 2004); Peter Eavis, 'No End to U.S. Housing Handouts', Wall Sircet Yournal, 24 March 2010, C16. 
wheels were coming off the financial system'. ${ }^{34}$ At that moment, emergency actions were needed to provide liquidity, and such actions were taken. As Anatole Kaletsky has explained: 'There are times, perhaps once in every generation, when the financial oscillations of greed and fear get out of control. At times like this, a political force from outside the market economy must intervene to moderate the financial cycle' ${ }^{35}$ But that was 2 years ago. In 2010 , the US economy remains weak with the growth rate falling in the most recent calendar quarter to $2.7 \%$ from the $5.6 \%$ rate that had been attained in the previous quarter. Clearly, the US government has been more adept in managing the worst of the crisis than in devising policies to generate new economic growth.

\section{ENHANCING ECONOMIC RECOVERY AND RESILIENCY}

In thinking about how to respond to the financial crisis, there are two distinct policy responses that need to be fine tuned. One is to put in place preventive and cleanup measures. The other is to make the economy stronger and more resilient so that it can recover from the effects of a credit crunch and recession. Specific suggestions for the USA are made in Section III.

\section{A. Boost competitiveness}

In summer 2010, unemployment remains stubbornly high, output is weak, and budget discipline nearly non-existent. As the US Competitiveness Policy Council explained in its first annual report, the components of a national competitiveness strategy (for any country) are attention to: saving and investment, education, worker training, critical technologies, corporate governance, trade, public infrastructure, and manufacturing. ${ }^{36}$ Unfortunately, this recipe for economic growth is not being followed in Washington. Space does not permit a full examination of the economic policies of the Obama Administration, but two areas (manufacturing and trade) will be briefly discussed below.

Instead of policies that promote manufacturing in general, the Bush and Obama Administrations settled on a strategy of bailing out GM, GMAC, and Chrysler with over $\$ 50$ billion in direct aid supplemented by millions of dollars in indirect aid through the 'Cash for Clunkers" ${ }^{37}$ program. 'Cash for Clunkers' soon became the leitmotif for a panoply of new, highly leveraged federal spending by the Obama Administration as money was channelled to pork-barrel projects that were too wasteful for local governments to fund

${ }^{34}$ See Paulson, above n 24, at 243.

${ }^{33}$ Anatole Kaletsky, 'The Benefits of the Bust', Wall Street Journal, 19-20 June 2010, W3.

${ }^{36}$ U.S. Competitiveness Policy Council, Building a Competitive America (March 1992).

${ }^{37}$ Car Allowance Rebate System program, http://www.cars.gov (visited 27 September 2010), 
themselves, a new alphabet of homeowner subsidies, and dubious job creation initiatives. The huge aid to the US automobile industry was especially troubling given that it undermined the long-held US policy stance that governments should not subsidize domestic automobile industries. The USA had participated in cases in the WTO against small automobile subsidies by Canada, Indonesia, and Australia. Yet now, the USA was signalling to the rest of the world that the US opposition to automobile subsidies had been opportunistic rather than principled.

Weak US trade policy is another factor exacerbating a lingering pain since the Great Contraction. Instead of making serious efforts to complete the Doha Development Round, to approve the three pending free trade agreements, and to launch new trade negotiations, the Obama Administration treats trade as a third rail of economic policy. Rather than a positive trade agenda of market opening, the Administration argues that the top priority should be enforcing trade agreements. Yet when the time comes for the USA to comply in the US - Zeroing ${ }^{38}$ cases and in the US - Upland Cotton ${ }^{39}$ cases, respect for the rule of law disappears in the White House. ${ }^{40}$

\section{B. Revive trade liberalization}

Completing the Doha Agenda would give a boost to the world economy and enhance the recovery from the financial crisis. As WTO Director-General Pascal Lamy has explained, the Doha Round can "deliver a very welcome stimulus package to the world economy... [o]ne that does not have to be financed out of national treasuries'. ${ }^{41}$ Unfortunately, US Trade Representative Ron Kirk has not skillfully engaged in unblocking the current impasse at the WTO.

One possible approach would be to transform the Doha Agenda into a true development round, ${ }^{42}$ and have the advanced economies swear off any

${ }^{38}$ WTO Appellate Body Report, United States - Measures Relating to Zeroing and Sunset Reviews - Recourse to Article 21.5 of the DSU by Japan, WT/DS322/AB/RW, adopted 31 August 2009; WTO Appellate Body Report, United States - Laws, Regulations and Merhodology for Calculating Dumping Margins ("Zeroing") - Recourse to Article 21.5 of the DSU by the European Communities, WT/DS294/AB/RW, 11 June 2009.

${ }^{39}$ Decision by the Arbitrator, United States Subsidies on Upland Cotton - Recourse to Arbitration by the United States under Article 22.6 of the DSU and Article 4.11 of the SCM Agreement, WTO Doc WT/DS267/ARB1, 09-4009; Decision by the Arbitrator, United States - Subsidies on Upland Cotton - Recourse to Arbitration by the United States under Article 22.6 of the DSU and Article 7.10 of the SCM Agreement, WTO Doc WT/DS267/ARB2, 09-4015, 31 August 2009.

40 'World Tariff Wars: U.S. Protectionism is Hurting American Exports', Wall Street fournal, 9 April 2010, A18.

41 Speech of Director-General Lamy, 'Drivers of Sustainable Growth', G-20 Business Summit, Toronto, 26 June 2010, http://www.wto.org/english/news_e/sppl_e/sppl160_e.htm (visited 17 September 2010).

${ }^{42}$ See Faizel Ismail, Reforming the World Trade Organization: Developing Countries in the Doha Round (Jaipur: CUTS, 2009) 120-21, 154. 
expectation of obtaining liberalization among themselves. Instead they could join together in offering significant concessions to help low-income countries. In my view, it would be easier to ratify a trade negotiation in the USA that delivers little to US exporters because it is not intended to do so, than to ratify a trade negotiation that is advertised as helping US exporrers when in fact it would not.

\section{Eradicate domestic content subsidies}

Although it has been many years since the USA was truly able to lead the world on trade, the Buy American policies championed by the Obama Administration and Congress have seriously undermined the reputation of the USA. While it is true that the USA is hardly the only country that has championed economic nationalism since the financial crisis, ${ }^{43}$ the fact that the USA was willing to do something so blatantly protectionist without evincing much embarrassment showed the world how little other countries could depend on the USA for leadership at a time of economic crisis. The American Recovery and Reinvestment Act ${ }^{44}$ of 2009 was unprecedented in size ( $\$ 787$ billion) and scope of subsidy ambition. The Act's BuyAmerican provision prohibits state and local governments from using newly provided federal aid for a public works project unless all of the iron, steel, and other manufactured goods used are produced in the USA. ${ }^{45}$

Much of the literature on this provision assumes that it is WTO-legal, ${ }^{46}$ but that hypothesis is questionable when one looks closely at the WTO law of subsidies, in particular Articles 1 and 3 of the Agreement on Subsidies and Countervailing Measures (SCM Agreement). The key question is whether a grant from the US federal government to subnational governments qualifies as a 'subsidy'. If it is a subsidy under the SCM Agreement, then this measure would seem to be a violation of SCM Article 3.1(b) because it would be a subsidy contingent upon domestic content.

The SCM Agreement does not clearly indicate whether a financial contribution from one WTO Member to another or a subsidy from one level of government to another is covered by the definition of subsidy in SCM

43 A recent study by Global Trade Alert lists the buy-national provision in the US stimulus package as being the secund largest of 22 jumbo protectionist measures enacted since November 2008. Simon J. Evenett and Johannes Fritz, "Jumbo" Discriminatory Measurea and the Trade Coverage of Crisis-Era Protectionism', in Evenett (ed) Global Trade Alert, Unequal Compliance: The $6^{\text {th }}$ GTA Repon, http://www.globaltradealert.org'sites/default/iles' GTA6.pdf (visited 27 June 2010) 49-58 at 55.

44 Public L. 115-5, approved 17 February 2009.

45 Section 1605, http://frwebgate.access.gpo.gov/cgi-bin/getdoc.cgirdbname $=111$ _cong_bills\&do cid=f:hl enr.pdf (visited 27 June 2010).

${ }^{46}$ For example, see Jagdish Bhagwati, 'Defending an Open World Economy', in Terry L. Anderson and Richard Sousa (eds), Reacting to the Spending Spree; Policy Changes We Can Afford (Stanford: Hoover Institution Press, 2009) 139-47, at 141-44. 
Article 1. Obviously, there is a benefit to the recipient, ${ }^{47}$ since a subnational government gets a direct transfer of funds. Consequently, the only definitional question is whether grants that go to individuals or to other governments, rather than to enterprises, are covered. In my view, US federal aid to states is not excluded from being a 'financial contribution' under the SCM Agreement and is distinguishable from funding movements that occur between agencies of the federal government. When the federal government gives budget aid to a state contingent on the use of domestic over imported goods, the goal of the federal government is to exert influence not only on how the federal dollars are spent but also on how the matching state dollars are spent. By using the lure of federal dollars, the Obama Administration was able to pressure states into not purchasing foreign-made goods even when states would have preferred a more cost-effective approach to building public works. ${ }^{48}$ To argue that no prohibited subsidy has occurred because the recipient is a government agency rather than an enterprise would be to.confound both the purpose and the letter of the SCM Agreement.

\section{Avoid demagoguery}

Finally, let me note one other dangerous aspect of the US President's economic policies, which is the constant anti-business thetoric from the White House. By fomenting public hatred of business, the government makes it harder for banks and businesses to engage in new investment and job creation. While there was certainly considerable unprincipled behavior by some banking executives who were at the centre of the financial crisis, I have seen no evidence that the private sector acted more irresponsibly than the public sector. In that regard; one can recall how during the Great Depression, John Maynard Keynes chided President Franklin D. Roosevelt for his criticism of businessmen with the sage advice that 'it is a mistake to think they are more immoral than politicians'. ${ }^{49}$

\section{IMPROVING INTERNATIONAL INSTITUTIONS IN FINANCIAL}

\section{REGULATION}

The success of the world trading system in knocking down trade barriers and in providing a robust system of enforcement has led some analysts to consider whether the WTO could take on a greater role in financial regulation.

${ }^{47}$ See Joseph Francois, 'Subsidies and Countervailing Measures: Determining the Benefit of Subsidies', in Kyle W. Bagwell, George A. Bermann and Perros C. Mavroidis (eds), Law and Economics of Contingent Protection in International Trade (Cambridge: Cambridge University Press, 2010) 103-115.

18 Jay L. Eizenstat, "Buy America": A Regrettable Step 'Toward Protectionism', BNA International Trade Reporter, 9 July 2009, 938.

49 John Maynard Keynes, Letter to Franklin D. Roosevelt, 1 February 1938. As quoted in Amity Shlaes, 'How to Make a Weak Economy Worse', Wall Street fournal, 2 February 2010, A19. 
This section considers that option and also examines the role of other international institutions toward correcting what went wrong during the financial crisis. A comparative institutional perspective will be used to make organizational design proposals by first examining the WTO, then the G8 and G-20, and then the ILO model.

\section{A. The role of the WTO}

Pascal Lamy has opined that the "The primary vocation of the WTO is to regulate, not to deregulate trade as is often thought. By putting in place rules to regulate trade flows and remove trade distortions, the WTO aims to create a global level playing field, where fairness is the rule and where the rights of individual members are safeguarded' ${ }^{50}$ These are weighty thoughts that deserve unpacking and response.

Because the WTO is aimed at the problem of government failure not market failure, ${ }^{51}$ the WTO has no general role in creating a global level playing field in the regulation of labor markets, antitrust, financial markets, ${ }^{52}$ and environmental protection. Nor does the WTO have a role in regulating trade flows of oil, endangered species, conflict diamonds, armaments, or many other commodities in which there is substantive international law. The only level playing ficld at issue in the WTO is the use of measures that distort trade such as subsidies, tariffs, and nontariff barriers.

While the WTO has some authority to promote a level playing field through regulation and harmonization, ${ }^{53}$ little of that nature has been accomplished: The WTO rules on accountancy ${ }^{54}$ are sometimes given as an example of how the WTO can legislate on financial services. An examination of these rules shows that they do not contain any international requirements for licensing

${ }^{50}$ Speech of Director-General Lamy, "Toward Shared Responsibiliry and Greater Coherence: Human Rights, Trade and Macroeconomic Policy', Geneva, 13 January 2010, http://www. wro.org/english/news_e/sppl_e/sppl146_e.htm (visited 17 September 2010). In an earlier speech, Lamy had declared: 'The WTO encourages, and will continuc to encourage, its members to abide by international norms'. Speech of Director-General Lamy, 'Global Problems, Global Solutions: Towards Better Global Governance', WTO Public Forum, Geneva, 28 September 2009, http://www,wto.org/english/news_e/sppl_e/sppll36_e.htm (visited 17 September 2010).

31 It is sometimes suggested that the Agreement on Trade-Related Aspects of Intellectual Property Rights (TRIPS) is an exceptional WTO agreement in addressing marker failure because it mandates that governments protect intellectual property (IP) rights. Although TRIPS docs not require that a government give IP rights to its nationals (sce TRIPS Agreement, Article 1.1), TRIPS does require the provision of IP rights to foreign nationals. One can look at this as a response to transborder market failure or as a response to a government failure of economic nationalism.

52 See Cortier and Krajewski in this volume, for a discussion of the deregulatory approach of General Agreement on Trade in Services (GATS).

${ }^{33}$ For example, see GATS, Arucle VI; General Agreement on Tariffs and Trade (GATT), Articles XVIII, XXVIII bis (3), XXXVI:I(e), XXXVII:3, XXXVIIl:2; Agreement on Technical Barriers to Trade (TBT Agreement), Articles 2.4, 12.6.

54 Disciplines on Domestic Regulation in the Accountancy Sector, S/L64, 14 December 1998. 
accountants with regard to minimum qualifications, but they do repeat the admonitions in the General Agreement on Trade in Services (GATS) regarding the creation of unnecessary barriers to trade. It is interesting to note that the GATS Council has not enacted similar legislation for other services. And even with all the mistakes that US regulators admit that they made in the US financial crisis, no one has argued that the insufficient US regulation constituted a violation of the GATS Annex on Financial Services.

In my view, seeking to assign the WTO the role of the super-regulator in financial services would be a mistake for many reasons. To start with, the WTO already has a critical role in promoting economic growth and sustainability. If the WTO were doing that more effectively, the world economy could be recovering more quickly from the financial crisis. Moreover, the pathologies of WTO decision-making, which have prevented the WTO from completing new agreements, would also prevent the WTO from acting to require better financial regulation.

The attractiveness of the WTO is that it contains hard law and accountability mechanisms for governments including the possibility of trade sanctions against a scofflaw. But this model cannot be used in other fields unless there is a similar agreement on what the hard law should be. In the field of trade, the hard law needed is to head off government failure. In the field of financial markets, the hard law needed is to address both government failure and market failure. Although there has been progress in the past few years (outside the WTO) in getting government agreement towards harmonizing financial regulation to address market failure, there has been little progress towards addressing government failure because major governments, like that of the USA, are not willing to give up their powers to borrow, subsidize, and redistribute income to favoured interests. Governments are also not willing to take responsibility for how their fiscal and regulatory practices affect other countries and to compensate other countries for the harm caused by transboundary financial pollution. So at present, hard law international solutions can only be pursued on limited facets of the problems that led to the financial crisis.

In contrast to using the WTO itself, it would be possible to borrow some of its techniques and employ them in other regimes. For example, the WTO's Trade Policy Review Mechanism (TPRM) could be adapted more broadly to deal with issues beyond trade. Already, climate change negotiators have been looking to replicate some aspects of the TPRM model. The current model features a report by the WTO Secretariat, a report and presentation by the government being reviewed, a commentary from a discussant, and then a discussion by WTO Members on the report followed by a response from the government being reviewed. Since the TPRM is not connected to the WTO dispute process, the government being reviewed does not have to defend whether it is complying with WTO law. Also, the topics 
to be discussed can go outside WTO rules. The benefit of this model is that each government's policy is reviewed individually based on analyses that have been prepared beforehand, and then documentation of this review is posted on the WTO website. The disadvantage of this model is that there is no opportunity for business or civil society to participate in the TPRM reviews. Grafting the TPRM model on to financial regulation would provide an opportunity for the revicw of the practices of key governments on a regular basis. No doubt, governments can ask each other questions in bilateral meetings, but on matters of interest to the world community, it would be better to have an organized process in place than to rely on normal diplomacy.

\section{B. The $G 8$ and $G-20$}

The G8 Summit of June 2010 produced the Muskoka Declaration: Recovery and New Beginnings. ${ }^{55}$ The Declaration begins by noting that the annual summit 'takes place as the world begins a fragile recovery from the greatest economic crisis in generations', ${ }^{56}$ but then curiously veers away from any substantive statement about the crisis in the remainder of the Declaration. Instead, the first issue treated in the Declaration is 'maternal health' and the G8 leaders report that progress in improving it has been 'unacceptably slow' ${ }^{57}$ Curiously, the Declaration does not explain exactly why maternal health is an international issue and certainly does not explain why it should be the top issue in the 2010 Declaration. International trade appears in one paragraph on page 6 of the Declaration wherein the Leaders pledge to "continue to resist protectionist pressures, and to promote liberalization of trade and investment under the WTO, through the national reduction of barriers, as well as through bilateral and regional negotiations. ${ }^{58}$ Free traders may be cheered, but it is unfortunate that G8 leaders did not explain how they could 'continue to' resist protectionist pressures when a major Report prepared for the Summits in Ontario found that 13 of 22 jumbo protectionist measures put in place since 2008 had been enacted by $\mathrm{G} 8$ countries. ${ }^{59}$

By contrast, the G-20 (which includes all G8 Members) did promulgate a Declaration over the same weekend that does address the recovery from the financial crisis. ${ }^{60}$ For example, the Declaration states:

We agreed that the core of the financial sector reform agenda rests on improving the strength of capital and liquidity and discouraging excessive

55 G8 Muskoka Declaration, Muskoka, 25-26 June 2010, http://www.whitehouse .gov/sites/defauluciles/g8_muskoka_declaration.pdf (visited 27 June 2010).

36 Ibid, para 1.

37 Ibid, para 8.

58 Ibid, para 26.

59 Evenett and Fritz, above n 43, at 55-57.

${ }^{60}$ G-20, 'Toronto Summit Declaration', Toronto, 26-27 June 2010, http://g20.gc.ca/torontosummit/summit-documents/the-g-20-toronto-summit-declaration/ (visited 28 June 2010). 
leverage. We agreed to increase the quality, quantity, and international consistency of capital, to strengthen liquidity standards, to discourage excessive leverage and risk taking, and reduce procyclicality. ${ }^{61}$

We agreed the financial sector should make a fair and substantial contribution towards paying for any burdens associated with government interventions, where they occur, to repair the financial system or fund resolution, and reduce risks from the financial system. ${ }^{62}$

In addition, the Declaration memorializes numerous other agreements in parallel language.

In my view, this G-20 Declaration fails to give law to world finance. In a Declaration of about 10,600 words, the word 'law' appears only twice and neither time in an international context. At no point does the Declaration read as a code or a binding instrument. The Declaration contains no indication that any of the agreements reached are to be enforced. Although the leaders say that they are 'committed to international assessment and peer review', ${ }^{63}$ no details are given. Another omission from the Declaration is any acknowledgment of state responsibility and liability for the impact of transboundary financial pollution.

The publication of a declaration of platitudes not moored to any accountability mechanism was made more likely when the summiteering governments failed to provide for nongovernmental participation, apart from a working session between the G-20 finance ministers and a conclave of senior business executives from G-20 countries. To be sure, there were some other parallel events, such as a Young Entrepreneur Summit with participation from each G-20 country, a meeting of 80 senior leaders of the world's religions and faith-based organizations, and a dialogue between the Canadian Sherpa and the transnational civil society delegation. Nevertheless, one can see no evidence that any of those ideas arising out of the parallel event were brought into the Summit itself. The business leaders did not make any formal proposals, but did post a summary of points made to the governments. ${ }^{64}$ Among the points made were that '[the] biggest worry shared by the business people in this room is the growing burden of government debt.... The next big worry for business is the continuing

The Declaration characterizes the G-20 as the 'premier forum' for international economic cooperation (para 1).

61 Ibid, Annex II, para 5.

${ }^{62}$ Ibid, para 21.

${ }^{63}$ Ibid, para 16.

44 G-20 Business Summit, 'Chairman's Summary', 26 June 2010, http://www.ceocouncil. ca/publications/pdE/test_b02eacab85823e18b154cc630e0bf3do/G20_Business_Summit_June 2526_Chairman_s_Summary.pdf (visited 27 June 2010). 
uncertainty about what governments are going to do on a number of important issues'. ${ }^{35}$

The G-20 Summit organizers did not host a sidebar meeting with international labour unions, which is a shame since the worker groups had been thoughtful enough to prepare and send a detailed 12-page list of recommendations in advance. ${ }^{66}$ The labour unions offered a number of interesting observations and recommendations, including, for example, that: (i) governments give priority to developing new sources of finance and support the development of a financial transactions tax (FTT) as a fair and practical means of paying for the crisis; (ii) the Financial Stability Board has not led to any concrete change and its reports reveal the extent to which supervisory authorities have lost control over global finance; (iii) the recent IMF proposals to reform the Basel II Framework represent too little too late; (iv) the Financial Stability Board needs to adopt formal consultation processes, and to publish documents for comment; (v) the ILO should help the OECD implement its new Declaration on Propriety, Integrity and Transparency in the Conduct of International Business and Finance. Although I do not agree with all of these points, note should be taken of how substantive the labour union recommendations are and how ministers agreed to meet with the business leaders but not the labour leaders. The Canadian Prime Minister, however, did receive the global union delegation which presented him with the vœu.

Although I am sure that the G-20 Summit of politicians and bureaucrats was interesting, this Summit would surcly have been better if there had been organized input from business, labour, legal analysts, environmentalists, and others. The G-20 Declaration offers normative guidance, and yet onc wonders whether the authoring bureaucrats drew from a wide enough range of data and ideas. As Thomas Cottier has noted: 'Theories alone cannot serve as a basis for the operation of markets and the exercise of discretionary powers in the real world'. ${ }^{67}$ Cottier further reminds the reader of how economic models need to be supplemented by input from the lawyer and in particular the relevance of values and justice, human experience and psychology, expertise in institutional design and in due process decision-making with fairness and transparency. The importance of a vibrant, open marketplace of ideas has been noted by social scientists for centuries. ${ }^{68}$

If it proves impractical for the G-20 to be more open to public input when drafting Declarations, then such policymaking should occur in other

65 Ibid, at 1 .

of International Trade Union Confederation, 'Take Action on Jobs to Sustain the Recovery, Global Unions' Statement to the G8/G20 Summits', June 2010, htcp:/www.ituc-csi .org/MMG/pdf/Final-Trade_Union_Statement_to_G20_Toronto.pdf (visited 27 June 2010).

${ }^{67}$ Cottier, above n 8 , at 12.

6н Thomas Butterworth, 'The Openness Elixir', Wall Street Journal, 19-20 June 2010, W8.' 
institutions which provide space for interdisciplinary analysis and public debate. The modern OECD is one such institution that could be tasked with serving as a forum for ideas on financial regulation, but the OECD is handicapped in its limited governmental membership. Another approach would be to establish an apparatus in the Financial Stability Board for public input, public participation, and multi-stakeholder dialogues. Ideally, the transnational labour unions and business leaders could have hashed out their conflicting views in public in Toronto in front of global leaders. In addition, whenever dialogues are prepared for the edification of financial regulators, there should be an economist or other participant designated to make the case in favour of free markets which often find themselves unrepresented at intergovernmental meetings.

Public input is also important to obtain at the national level. Indeed, it may be even more important at that level. ${ }^{69}$ Thus, the G-20 could usefully call on governments to improve their administrative law public disclosure and notice and comment processes and to require national regulators to consult with regulated entities, investors, consumers, and civil society.

\section{The ILO model}

Another international model that can be drawn upon is the annual review by the ILO of the reports submitted pursuant to the ILO Declaration on Fundamental Principles and Rights at Work. ${ }^{70}$ Under this arrangement, now a decade old, each government submits its own report on the status of relevant domestic rights relating to the core ILO conventions that it has not ratified. The reports are then reviewed by the Committee of Independent Expert Advisers. In turn, their observations are considered by the ILO's Governing Body where employers and workers organizations are given an opportunity to comment on these reports. This process, which has received much less international attention than the TPRM, is more progressive in providing for comment by employer and worker organizations.

\section{CONCLUSIONS}

It was already evident by 1923 that the world economy needed better law. The ensuing decades have crystallized the perceptiveness of that early insight. Yet as this article points out, none of the international institutions overseeing financial regulation operates through the rule of law in a similar style to that of the WTO. But that situation is not intolerable as leading governments and publics are probably not ready to legalize international

69 See Weber, in this issue at 683-704.

${ }^{70}$ ILO Governing Body, 'Review of annual reports under the follow-up to the lLO Declaration on Fundamental Principles and Rights at Work', GB/307/3, March 2010. 
financial rules in the same way that they have legalized international trade rules. Because the best approach to building law is from the bottom up, the proper degree of authoritative decision-making for international financial matters remains at the stage of best practices and soft law standards. ${ }^{71}$

Although this article does not criticize the lack of hard law and hierarchy in international financial market oversight, it does raise two other criticisms. First, the problematique in much of the literature is to assume that all social problems stem from market failure. In my view, the problem of government failure is at least as serious. ${ }^{72}$ The US financial crisis did not ensue because there was too much speculation. Rather, speculation increased because the value of many widely held assets became uncertain. Because government policies had artificially inflated housing prices, hundreds of billions of dollars of securities were being misvalued. Because government policies had built-in expectations of welfare state and bailout, the phenomenon of moral hazard expanded. When financial legislation responds only to the symptom of a problem and not to its cause, such legislation will not succeed in promoting economic growth and in preventing furure financial calamities.

Second, the optimal international institutions to manage financial markets will be transparent and deliberative. ${ }^{73}$ Although there can be a need for national regulators to act in secrecy, the international level should be open in order to bring a broad array of views to bear and to expose government actions that seek to impose costs on other countries. Transnational civil society and business should have an opportunity to participate in dialogues with regulators so that the problems of government failure can be exposed. Just as market failure has to be corrected through intervention from outside the market, government failure has to be corrected through intervention from outside bureaucrats and politicians. In 2009, at the UN Conference on the World Financial and Economic Crisis and its Impact on Development, the General Assembly suggested the possibility of establishing an ad hoc panel of experts to provide independent technical expertise in order to inform better international action and policy decision-making. ${ }^{74}$ Such an independent panel has not yet been set up within the UN Economic and Social Council.

In summary, the world economy needs a better law of financial markets and such law needs to be responsive to the problems of both market and government failure. The regulation of financial markets is a transnational

71 See Brummer, in this issue at 623-643.

${ }^{72}$ Gerald P. O'Driscoll Jr. 'The Gulf Spill, the Financial Crisis and Government Failure', Wall Street Journal, 14 June 2010, A17.

${ }^{73}$ Daniel C. Esty, 'Good Governance at the Supranational Scale: Globalizing Administrarive Law', 115 Yale Law Journal 1490 (2006), at 1520.

${ }^{74}$ A/Res/63/303, 13 July 2009, para 56. 
problem because markets overlap political borders, but is also a transnational problem because sovereign governments need positive reinforcement from global institutions. Optimal global institutions will not merely comprise the governments to be overseen. Rather, international institutions can benefit from systematic input from international civil servants, business, and civic society. 